\title{
Nutritional effects on the fetus and mammary gland during pregnancy
}

\author{
By D. J. MeLloR, Moredun Research Institute, 408 Gilmerton Road, Edinburgh \\ EHI $77 \mathcal{F H}$
}

Reproduction can be regarded as successful only if viable young are born and reared. During the period between conception and birth, anabolic processes concerned with growth of the placenta, fetus and mammary gland and with lactogenesis must be supported by adequate supplies of nutrients, because deficiencies in nutrient supply for these crucial activities can jeopardize the survival or well-being of the young. In addition, if the demands for nutrients exceed the capacity of the mother to meet them, her well-being can be threatened too. Thus, it is important to effect a balance between the quantities of absorbed nutrients and the tissue demands for energy and nitrogen, and in order to achieve this objective it is helpful to understand when the different anabolic activities are vulnerable to nutritional insult and how they interact physiologically. The present discussion will deal with these phenomena in sheep and women. Effects of changes in the general level of nutrition will be considered but not effects of imbalances of specific nutrients. The sheep is important in its own right, and during the past 20 years its fetus has been used increasingly as an experimental model of the human fetus. Although distinct differences between the two species caution against direct transposition of the results, various principles demonstrated in sheep can aid interpretation of clinical findings in man. Similarities and differences between the two species will therefore be considered.

Growth of the fetus at any time results from the balance between its inherent growth drive, reflected by its demands for nutrients, and the limits imposed on the supply of substrates by placental size and maternal nutritional state. It is worth distinguishing between fetal nutrition and maternal nutrition because this helps to clarify the often confounding effects on the fetus of placental size and maternal nutrition. For instance, fetal undernutrition and the associated intrauterine growth retardation occur in well-fed mothers when placental size is restricted and in undernourished mothers whatever the placental size, although it should be noted in the latter case that a large placenta can partly offset the deleterious effects of maternal undernutrition. Placental size is clearly of pivotal significance in these interactions and will therefore be considered first.

\section{The placenta and overall fetal growth}

Placental size. The growth patterns of the placenta, indicated by weight or volume changes, differ in the two species. In sheep, after implantation at about 4 weeks of gestation, placental weight increases, reaching maximum values at about 
I 3 weeks ( 0.62 of gestation) and thereafter it remains fairly constant until term at about 21 weeks (Mellor, 1983). In women, the weight and volume of the placenta increase throughout pregnancy, but there is a decrease in placental growth rate between about 36 weeks ( 0.90 of gestation) and term at about 40 weeks (Aherne \& Dunnill, 1966; Hytten \& Leitch, 1971).

The overall growth of the placenta varies widely in healthy individuals, the ranges in size at term being $100-650 \mathrm{~g}$ in sheep (Mellor, 1983 ) and $240-725 \mathrm{~g}$ or ml in women (Aherne \& Dunnill, 1966; Sciarra et al. 1968). Most of this variation remains unexplained, but in sheep one inhibitory factor is moderate or severe maternal undernutrition during the period of placental growth between 4 and 13 weeks of gestation (Everitt, 1964; Alexander \& Williams, 1971). As placental growth continues until term in women (Aherne \& Dunnill, I966; Hytten \& Leitch, 1971) it is interesting to speculate that the human placenta may be vulnerable to nutritional insult during most of pregnancy. Thus, effects on the placenta of starvation or marked reductions in food intake during periods of illness merit investigation.

Placental size and the fetus. Although placental weight is probably a fairly crude index of transfer capacity (Aherne \& Dunnill, I 966; Makowski et al. 1968a,b), it is of interest that in normal pregnancies the term weights of the placenta and the fetus are correlated positively, the correlation coefficients being about 0.87 and 0.50 in sheep and women respectively (Sciarra et al. 1968; Mellor, 1983). This association, which has also been observed in placental ablation studies (Mellor, 1983; Falconer et al. 1985), is usually considered to indicate that placental size is an important determinant of fetal growth rate. However, this would be true only if placental development were predominantly independent of fetal influences, which is not likely, because embryologically the placenta is a fetal organ and there is increasing evidence that substrates for placental metabolism are derived from fetal blood (Hay et al. 1984; Bassett et al. 1985; J. C. Hodgson, D. J. Mellor and A. C. Field, unpublished results). Metabolic and other interactions between the fetus and placenta are clearly worthy of further experimental attention.

Placental size influences the physiological state of the new-born. This is evident particularly in cases of intrauterine growth retardation associated with placental insufficiency. Low-birth-weight young of this type experience chronic prenatal hypoxaemia . which postnatally inhibits the establishment of spontaneous respiration and the necessary rises in heat production, thus increasing the incidence of asphyxia and hypothermia (Brans \& Cassady, 1975; Robinson, 1979; Mellor, 1983). They also exhibit a high incidence of hypoglycaemia as a result of a prenatal energy deficiency which restricts the deposition of, or depletes, body energy reserves required for metabolism after birth, but the particular substrates which are affected differ in sheep and humans (see Mellor \& Cockburn, 1986). On the other hand, when low birth weight is due to maternal undernutrition (lambs) or premature birth (infants) and not to placental insufficiency, chronic prenatal hypoxaemia and its consequences are absent, but the tendency toward postnatal hypoglycaemia remains (Mellor, 1983; Mellor \& Cockburn, 1986) and the 
well-being of preterm infants can also be threatened by other aspects of their physiological immaturity (Robinson, 1979).

\section{Fetal growth patterns}

The growth patterns of individual fetuses have been determined in sheep from about I I weeks ( 0.52 of gestation) using a simple device for measuring the curved crown-rump length (CRL) or thoracic girth (Mellor \& Matheson, 1979; Mellor \& Murray, $1982 b)$ and in women from about 13 weeks $(0.33$ of gestation) using ultrasound measurement of the biparietal diameter of the skull (Campbell, r 974; Robinson, 1979; Jeanty et al. 1984). During the later half of pregnancy in well-fed sheep, fetal growth rate remains constant until about 17 weeks ( 0.81 of gestation) and then decreases progressively until term, the mean rate during the last 4 weeks being correlated positively with placental weight (Mellor \& Murray, I 981, I982b). A similar fetal growth pattern is evident in healthy women, the decline in rate occurring from about 32 weeks (0.80 of gestation) (Campbell, 1974; Jeanty $e t$ al. 1984), but there is apparently no information on the relation between placental weight and fetal growth rate during the last 8 weeks of pregnancy, although it is likely that a positive correlation exists (Campbell, 1974; Robinson, 1979). In the well-fed healthy female of both species, therefore, abrupt changes in fetal growth rate are unusual during late pregnancy.

However, the pattern of fetal growth can be disturbed in sheep when the plane of maternal nutrition is altered suddenly (Mellor \& Matheson, 1979; Mellor \& Murray, $1981,1982 a, b)$. When well-fed ewes are abruptly and severely underfed during late pregnancy, as might occur after heavy snowfalls, fetal growth rate decreases immediately by about $40 \%$, and when the severe underfeeding continues for more than 2 weeks, the growth rate decreases even more. Fetal growthresponses to refeeding the ewe depend on the duration of underfeeding. For example, when ewes are refed after $16 \mathrm{~d}$ or less of severe underfeeding, fetal growth rate increases again, but the growth lost is not made good during refeeding. In contrast, refeeding ewes after $21 \mathrm{~d}$ or more of underfeeding does not increase fetal growth rate, but it does prevent the progressive decrease in rate which occurs when the undernutrition continues. These observations demonstrate a marked sensitivity of fetal growth rate to changes in ewe nutrition in late pregnancy. It is not known whether human fetal growth is equally sensitive to abrupt reductions in maternal food intake, but a comparison of the gross energy (GE) requirements suggests that it might be, because the daily increases in GE intake needed during the last 0.15 of pregnancy are less in ewes than in women. The increments required are about 50 and $180 \mathrm{~kJ} / \mathrm{d}$ per kg new-born weight in ewes and women respectively, representing 0.015 and 0.06 of their corresponding daily GE intakes at term (Agricultural Research Council, 1980; Durnin et al. 1985). It is known, however, that human fetal growth can decrease dramatically or even cease in conditions which reduce placental perfusion (Campbell, 1974; Persson et al. 1978a); furthermore, during late pregnancy fetal growth rate decreases more in 
twins than in singles and when mothers are smokers (Grennert et al. 1978; Persson et al. $1978 b)$.

\section{Size at birth}

Markedly premature birth is unusual in sheep, so that a low birth weight indicates a priori that fetal growth retardation has occurred. However, the converse, that average or above average birth weights indicate the absence of retarded growth, is not as certain because of the possible confounding effects of placental size and maternal nutrition. Placental weight varies widely in uniformly treated ewes and there is an associated wide range of birth weights, but the relation between the two depends on the plane of nutrition (Mellor, 1983). For instance, in well-fed Scottish Blackface ewes a placental weight of $650 \mathrm{~g}$ is associated with a birth weight of about $6.4 \mathrm{~kg}$, whereas in animals which are underfed for the last 4 weeks of pregnancy the same placental weight supports lambs which weigh about $5.1 \mathrm{~kg}$ at birth, and this birth weight is similar to the mean for well-fed ewes (Mellor \& Murray, I98I ; Mellor, 1983). Thus, the use of birth weight alone can suggest that fetal growth has not been impeded, when reference to the placental weight as well or to daily changes in CRL or girth demonstrates the reverse.

The question arises of whether body conformation (CRL:weight or girth:weight) of lambs at birth can be used to distinguish between fetal growth retardation caused by placental insufficiency and that caused by maternal undernutrition. Unfortunately, the equations describing the relations between the CRL:weight $\left(\mathrm{R}_{\mathrm{CRL}}\right)$ or girth:weight $\left(\mathrm{R}_{\text {girth }}\right)$ and weight $(\mathrm{W})$ are similar whether the range of birth weights arises because of variations in placental size or maternal nutrition, or both (D. J. Mellor, unpublished results). The equations for pooled values from 100 Scottish Blackface lambs in the six groups described by Mellor (1983) are:

$$
\begin{aligned}
& \mathrm{R}_{\mathrm{CRL}}=2.18+\mathrm{I} \cdot 30 \mathrm{~W} r^{2} 0.95, \\
& \mathrm{R}_{\text {girth }}=4.02+\mathrm{I} .85 \mathrm{~W} r^{2} 0.95,
\end{aligned}
$$

where $R_{C R L}$ and $R_{\text {girth }}$ are expressed as $\mathrm{mm} / \mathrm{kg}$ and $W$ as $\mathrm{kg}$. It follows that $R_{\mathrm{CRL}}$ and $R_{\text {girth }}$ of lambs at birth cannot be used to distinguish the different types of growth retardation, and this would probably also be true of the specific organ weight: body-weight ratios (Robinson \& McDonald, r 979). However, polycythaemia and hyperlactacidaemia at birth indicate chronic prenatal hypoxaemia due to placental insufficiency (Mellor, 1983), so that their presence or absence in low-birth-weight lambs is diagnostic.

Compared with sheep, premature birth is common in women and it is therefore obvious that birth weight alone does not permit an unequivocal diagnosis of growth retardation, even with very-low-birth-weight infants. The minimum diagnostic criterion is a weight-fetal age comparison, but when fetal age is not known precisely, relations between the sizes of different body parts can aid 
interpretation (Campbell, 1974). However, confusion can arise because the body proportions of growth-retarded infants near term are often appropriate to earlier fetal ages (Campbell, 1974). It is not known whether or not fetal growth retardation can precede the birth at term of 'normal' weight infants, as can occur with lambs.

\section{Mammary growth and its relation to fetal growth}

Sheep. In sheep at term, the weight of mammary tissue averages $0.3-0.4$ of the total lamb weight for litter sizes of two to four (Robinson et al. 1977, 1978; Mellor \& Murray, 1985a), which indicates that over the whole of pregnancy the metabolic cost of mammary development is less than the cost of fetal growth. However, about 0.7 of the increase in mammary weight occurs during the last 4 weeks of pregnancy (Robinson et al. 1978), so that over the shorter period it may be calculated that the energy costs of mammary and fetal growth are similar (Mellor \& Murray, $1985^{a}$ ). Therefore, by ignoring the growth of mammary tissue the Agricultural Research Council (1980) recommendations underestimate the energy requirements for tissue synthesis during late pregnancy; Robinson (1983) reached a similar conclusion about the protein requirements. It is therefore not surprising that severe maternal undernutrition during late pregnancy causes an immediate reduction in mammary growth rate (Mellor \& Murray, $1985 a$ ).

The growth patterns of the ovine mammae and fetus during late pregnancy are opposite, and this difference is evident particularly during severe undernutrition. Although mammary growth rate is reduced during undernutrition, it still increases progressively throughout, showing a marked increase during the last $5 \mathrm{~d}$ before birth (Mellor \& Murray, $1985 a$ ). In contrast, fetal growth rate decreases progressively and approaches zero during the last few days (Mellor \& Murray, $1981,1982 a, b$; Mellor, 1983). It is tempting to conclude that nutritionally deprived ewes can redirect substrate away from the fetus towards mammary tissue, but experiments designed to quantify the partitioning of nutrients between the different tissues are required to clarify this point. Whatever the mechanism, the ability of nutritionally deprived ewes to promote mammary growth just before birth may improve lamb survival, because although the deficit in body energy reserves caused by maternally induced fetal undernutrition cannot be corrected by refeeding ewes to well-fed levels during the last 2 weeks of pregnancy, its deleterious effects in the new-born can be overcome by adequate intakes of colostrum and milk during the first few hours after birth (Mellor \& Murray, $1985 b$; Mellor \& Cockburn, 1986).

The mechanisms responsible for the different effects of undernutrition on fetal and mammary tissue are of considerable interest. They are likely to involve largely autonomous fetal and maternal endocrine responses to the nutrient deficiency (Bassett \& Madill, 1974; Mellor et al. 1977; Slater \& Mellor, 1981), but their characteristics require clarification. Although fetal growth and hormonal responses to placental insufficiency have been examined (Jones \& Robinson, 1979, 1983; 
Robinson et al. 1979, 1980; Falconer et al. 1985), changes associated with long periods of reduced maternal feed intake, as opposed to short periods of starvation (Bassett \& Madill, 1974; Schreiner et al. 1980), have not. Also, there is apparently no published information about effects of maternal hormones on mammary development during late pregnancy undernutrition, but information from the ewes examined by Mellor \& Murray (1985a) show that terminal increases in plasma growth hormone levels and in mammary growth rate occur simultaneously (D. J. Mellor, D. J. Flint and R. G. Vernon, unpublished results) and thus implicate growth hormone.

The mechanisms which link prenatal mammary and fetal growth are also of interest because the mammary :lamb weight ratio at term is fairly uniform both for a range of litter sizes (Robinson et al. 1977, 1978; Mellor \& Murray, 1985a) and a range of feeding levels during late pregnancy (Rattray et al. 1974; Mellor \& Murray, $1985 a$ ). The placenta may have a key role in this relation. It not only affects fetal growth (see p. 250), but it is also the source of ovine placental lactogen (oPL), a polypeptide hormone which has mammogenic properties (Knight \& Peaker, 1982; Schams et al. 1984).

The oPL concentrations in maternal plasma increase markedly after 14 weeks of gestation and approach maximum values between 17 and 19 weeks (Chan et al. 1978; Oddy \& Jenkin, 198I; H. Wright and D. J. Mellor, unpublished results from Mellor \& Murray, 198I), so that most mammary development occurs when oPL concentrations are high. Furthermore, plasma oPL concentrations at each stage of gestation are correlated positively with placental weight. Maximum oPL concentrations and total placental weight both increase as litter size increases (Martal \& Djiane, 1977; Robinson et al. 1977; Chan et al. 1978; Oddy \& Jenkin, $198 \mathrm{I} ; \mathrm{H}$. Wright and D. J. Mellor, unpublished results), and significant differences in oPL concentrations between single- and twin-bearing ewes $(\mathrm{H}$. Wright and $\mathrm{D}$. J. Mellor, unpublished results) and in single-bearing ewes between those with large and small placentas (Falconer et al. 1985), disappear when corrected for placental weight. However, although there seem to be positive correlations between total placental weight, maximum oPL concentrations and mammary weight over several litter sizes, the situation within a particular litter size is apparently less consistent (H. Wright and D. J. Mellor, unpublished results), which suggests that other factors cause variations in mammary growth within ranges set by the level of oPL secretion. One of these factors might be placental progesterone; it is secreted in large amounts during the last half of pregnancy, its plasma concentrations increase as litter size increases and it has mammogenic properties (Bassett et al. 1969; Emardy et al. 1974; Ricketts \& Flint, I980; Knight \& Peaker, 1982). However, its precise effects on mammary growth have not been quantified.

Women. In women, overall mammary growth is small compared with fetal growth and by term the increment in mammary weight is about 0.12 of the infant's weight (Hytten \& Leitch, 1971), which indicates that the energy and protein costs of mammary development are small compared with the demands for synthesis of other tissues. Furthermore, unlike sheep, the growth patterns of 
mammary tissue and the fetus are similar, as both exhibit a decrease in growth rate during the last 8-10 weeks of pregnancy (Hytten \& Leitch, I97I; Campbell, 1974). The human placental lactogen (hPL) concentrations in maternal plasma increase during pregnancy, reaching peak values at about 37 weeks, after which they do not change or they show a small decrease (Grumbach et al. 1968; Saxena et al. 1969; Rolschau et al. 1975). After 37 weeks the maternal concentrations are correlated positively with placental weight, and therefore also with fetal weight, and are generally higher in women with twin fetuses than in those with single fetuses (Grumbach et al. 1968; Sciarra et al. 1968; Saxena et al. 1969; Seppala \& Ruoslahti, 1970; Rolschau et al. 1975). Relations between hPL concentrations and mammary size apparently have not been examined.

Although placental lactogen in maternal plasma may be important for mammogenesis in both species, its putative function as a promoter of fetal growth by metabolic actions in the mother (Grumbach et al. 1968; Taylor, 1980; Brinsmead et al. 198I) has yet to be established (Waters et al. 1985). Thus, the positive correlations between peak placental lactogen concentrations in maternal plasma and total fetal weight could be fortuitous, arising because the supply of nutrients to the fetus and the production of lactogenic hormone by the placenta, although largely independent, are both quantitatively related to placental weight.

\section{Lactogenesis}

The onset of milk secretion, or lactogenesis, exhibits different patterns in sheep and women. In well-fed ewes with one or two lambs, large volumes of colostrum accumulate in the mammary glands during the last few days of pregnancy and copious milk secretion begins soon after birth, so that averages of $1800-\mathbf{2 8 0 0} \mathrm{ml}$ colostrum and milk are produced during the first $18 \mathrm{~h}$ (Mellor \& Murray, $1985 a$, 1986). In underfed ewes, prenatal colostrum accumulation is reduced markedly, lactogenesis is delayed and the total production of colostrum and milk during the first $18 \mathrm{~h}$ averages about $1000 \mathrm{ml}$ (Mellor \& Murray, $1985 a$ ). Subsequently in both types of ewe, milk production increases, reaching a peak about $\mathrm{I}-2$ weeks after birth (Treacher, 1970; Doney et al. 1979). In contrast, in women there is virtually no prenatal accumulation of colostrum, production during the ist day after birth averages $36 \mathrm{ml}$ and it takes $5-6 \mathrm{~d}$ for daily milk production to rise to about $1000 \mathrm{ml}$ (Roderuck et al. 1946; Saint et al. 1984). An important cause of this species difference may be the faster disappearance of progesterone from maternal plasma at birth in sheep (Bassett et al. 1969; D. J. Mellor, D. J. Flint and R. G. Vernon, unpublished results) than in women (Yannone et al. I968; Kulski et al. 1977), because progesterone withdrawal allows prolactin, acting with cortisol, to stimulate lactogenesis (Delouis, 1978; Delouis et al. 1980). Furthermore, compared with well-fed sheep, progesterone withdrawal in underfed animals is delayed (D. J. Mellor, D. J. Flint and R. G. Vernon, unpublished results) and may therefore contribute to the delaying effects of undernutrition on lactogenesis in ewes. Clearly, the nutrition-endocrine interface as it affects lactogenesis in different species could be a fruitful area of study. 


\section{REFERENCES}

Agricultural Research Council (1980). The Nutrient Requirements of Ruminant Livestock, pp. I 15-1 16. Slough: Commonwealth Agricultural Bureaux.

Aherne, W. \& Dunnill, M. S. (1966). British Medical Bulletin 22, 5-8.

Alexander, G. \& Williams, D. (1971). Fournal of Agricultural Science, Cambridge 76, 53-72.

Bassett, J. M., Burks, A. H. \& Pinches, R. A. (1985). In Physiological Development of the Fetus and Newborn, pp. 7I-76 [C. T. Jones and P. W. Nathanielsz, editors]. London: Academic Press.

Bassett, J. M. \& Madill, D. (1974). Fournal of Endocrinology 61, 465-477.

Bassett, J. M., Oxborrow, T. J., Smith, I. D. \& Thorburn, G. D. (1969). Fournal of Endocrinology 45, 449-457.

Brans, Y. W. \& Cassady, G. (1975). In The Placenta and its Maternal Supply Line: Effects of Insufficiency on the Fetus, pp. 307-334 [P. Gruenwald, editor]. Lancaster: Medical and Technical Publishing.

Brinsmead, M. W., Bancroft, B. J., Thorburn, G. D. \& Waters, M. J. (1981). Fournal of Endocrinology 90, 337-343.

Campbell, S. (1974). In Size at Birth, Ciba Foundation Symposium no. 27, pp. 275-293. Amsterdam: Elsevier.

Chan, J. S. D., Robertson, H. A. \& Freisen, H. G. (1978). Endocrinology 102, 1606-1613.

Delouis, C. (1978). Annales de Recherches Veterinaires 9, 193-203.

Delouis, C., Djiane, J., Houdebine, L. M. \& Terque, M. (1980). Fournal of Dairy Science 63, $1492-1513$.

Doney, J. M., Peart, J. N., Smith, W. F. \& Louda, F. (1979). Journal of Agricultural Science, Cambridge 92, $123-132$.

Durnin, J. V. G. A., McKillop, F. M., Grant, S. \& Fitzgeraid, G. (1985). Lancet ii, 823-825.

Emardy, M., Hadley, J. C., Noakes, D. E. \& Arthur, G. H. (1974). Veterinary Record 95, 168-169.

Everitt, G. C. (1964). Nature 201, 1341-1342.

Falconer, J., Owens, J. A., Allotta, E. \& Robinson, J. S. (1985). Fournal of Endocrinology 106, 7-11.

Grennert, L., Persson, P. H. \& Gennser, G. (1978). Acta Obstetrica Gynecologica Scandinavica 78, 28-32.

Grumbach, M. M., Kaplan, S. L., Sciarra, J. J. \& Burr, I. M. (1968). Annals of the New York Academy of Science 148, $501-531$.

Hay, W. W., Sparks, J. W., Battaglia, F. C. \& Meschia, G. (1984). American fournal of Physiology 246, $\mathrm{E}_{528}-\mathrm{E}_{534}$.

Hytten, F. E. \& Leitch, I. (1971). The Physiology of Human Pregnancy. Oxford: Blackwell Scientific Publications.

Jeanty, P., Cantraine, F., Romero, R., Cousaert, E. \& Hobbins, J. C. (1984). Fournal of Ultrasound Medicine 3, 321-328.

Jones, C. T. \& Robinson, J. S. (1979). In Maternal Effects in Development, British Society for Developmental Biology Symposium no. 5, pp. 395-409 [D. R. Newth and M. Balls, editors]. Cambridge: Cambridge University Press.

Jones, C. T. \& Robinson, J. S. (1983). Fournal of Developmental Physiology 5, 77-87.

Knight, C. H. \& Peaker, M. (1982). Fournal of Reproduction and Fertility 65, $521-536$.

Kulski, J. K., Smith, M. \& Hartmann, P. E. (1977). Journal of Endocrinology 74, 509-510.

Makowski, E. L., Meschia, G., Droegemeuller, W. \& Battaglia, F. C. (1968a). American fournal of Obstetrics and Gynecology 101, 409-4I 2.

Makowski, E. L., Meschia, G., Droegemeuller, W. \& Battaglia, F. C. (1968b). Circulation Research XXIII, 623-631.

Martal, J. \& Djiane, J. (1977). Fournal of Reproduction and Fertility 49, 285-289.

Mellor, D. J. (1983). British Veterinary Yournal 1 39, 307-324.

Mellor, D. J. \& Cockburn, F. (1986). Quarterly Yournal of Experimental Physiology 71, 361-379.

Mellor, D. J. \& Matheson, I. C. (I979). Quarterly fournal of Experimental Physiology 64, II 13 I.

Mellor, D. J., Matheson, I. C. \& Small, J. (1977). Research in Veterinary Science 23, I 19-1 21. 
Mellor, D. J. \& Murray, L. (198I). Research in Veterinary Science 30, 198-204.

Mellor, D. J. \& Murray, L. (1982a). Research in Veterinary Science 32, 177-180.

Mellor, D. J. \& Murray, L. (1982b). Research in Veterinary Science 32, 377-382.

Mellor, D. J. \& Murray, L. (1985a). Research in Veterinary Science 39, 230-234.

Mellor, D. J. \& Murray, L. (1985b). Research in Veterinary Science 39, 235-240.

Mellor, D. J. \& Murray, L. (1986). Veterinary Record I 18, 35 1-353.

Oddy, V. H. \& Jenkin, G. ( 1981 ). Proceedings of the Nutrition Society of Australia 6, 151.

Persson, P. H., Grennert, L. \& Gennser, G. (1978a). Acta Obstrica Gynecologica Scandinavica $78,40-48$.

Persson, P. H., Grennert, L., Gennser, G. \& Kullander, S. (1978b). Acta Obstrica Gynecologica Scandinavica 78, 33-39.

Rattray, P. V., Garrett, W. N., East, N. E. \& Hinman, N. (1974). Fournal of Animal Science 38, $613-626$.

Ricketts, A. P. \& Flint, A. P. F. (1980). Fournal of Endocrinology 86, 337-347.

Robinson, J. J. (1983). In Sheep Production, pp. I1 1-131 [W. Haresign, editor]. London: Butterworths.

Robinson, J. J. \& McDonald, I. (1979). Annales Biologie Animale Biochimie et Biophysique 19, 225-234.

Robinson, J. J., McDonald, I., Fraser, C. \& Crofts, R. M. J. (1977). Fournal of Agricultural Science, Cambridge 88, 539-552.

Robinson, J. J., McDonald, I., McHattie, I. \& Pennie, K. (1978). Fournal of Agricultural Science, Cambridge 91, $291-304$.

Robinson, J. S. (1979). British Medical Bulletin 35, 137-1 44.

Robinson, J. S., Hart, I. C., Kingston, E. J., Jones, C. T. \& Thorburn, G. D. (1980). Fournal of Developmental Physiology 2, 239-248.

Robinson, J. S., Kingston, E. J., Jones, C. T. \& Thorburn, G. D. (1979). Yournal of Developmental Physiology I, 379-398.

Roderuck, C., Coryell, M. N., Williams, H. H. \& Macy, I. G. (1946). Fournal of Nutrition 32, $267-283$.

Rolschau, J., Date, J., Kristoffersen, K., Pedersen, G. T. \& Ulrich, M. (1975). Acta Obstetrica Gynecologica Scandinavica 54, 341-346.

Saint, L., Smith, M. \& Hartmann, P. E. (1984). British Fournal of Nutrition 52, 87-95.

Saxena, B. N., Emerson, K. \& Selenkow, H. A. (1969). Nero England Journal of Medicine 281, $225^{-231}$.

Schams, D., Russe, I., Schallenberger, E., Prokopp, S. \& Chan, J. S. D. (1984). Fournal of Endocrinology 102, $121-130$.

Schreiner, R. L., Nolen, P. A., Bonderman, P. W., Moorehead, H. C., Gresham, E. L., Lemons, J. A. \& Escobedo, M. B. (1980). Pediatric Research 14, $103-108$.

Sciarra, J. J., Sherwood, L. M., Varma, A. A. \& Lundberg, W. B. (1968). American Yournal of Obstetrics and Gynecology I01, 413-4I6.

Seppala, M. \& Ruoslahti, E. (1970). Acta Obstetrica Gynecologica Scandinavica 49, 143-147.

Slater, J. S. \& Mellor, D. J. (1981). Research in Veterinary Science 31, 224-230.

Taylor, M. J. (1980). In Hormones and Metabolism in Ruminants, pp. 112-121. London: Agricultural Research Council.

Treacher, T. T. (1970). Animal Production 12, 23-36.

Waters, M. J., Oddy, V. H., McCloghy, C. E., Gluckman, P. D., Duplock, R., Owen, P. C. \& Brinsmead, M. W. (1985). Fournal of Endocrinology 106, 377-386.

Yannone, M. E., McCurdy, J. R. \& Goldfien, A. (1968). American foumal of Obstetrics and Gynecology 101, 1058-1061. 